\title{
Kompetensi Perawat Dalam Menetapkan Diagonasa Keperawatan
}

\section{Riana Silvia Casuarina L.Tobing}

\section{riana.sct@gmail.com}

\section{Latar belakang:}

Kompetensi merupakan kewenangan (kekuasaan) untuk menentukan (memutuskan sesuatu),kemampuan menguasai gramatika suatu bahasa secara abstrak atau batiniah. Kompetensi perawat adalah refleksi kompetensi yang harus dimiliki oleh perawat untuk memberikan asuhan keperawatan professional (PPNI, 2013). Penjabaran area kompetensi perawat indonesia salah satunya pemberi asuhan dan manajemen asuhan keperawatan yang meliputi menerapkan prinsip dasar dalam pemberian asuhan keperawatan dan pengelolaannya, melaksanakan upaya promosi kesehatan dalam pelayanan maupun asuhan keperawatan, melakukan pengkajian keperawatan, melakukan analisis data dan merumuskan diagnosa keperawatan, menyusun rencana keperawatan, melaksanakan tindakan keperawatan sesuai rencana, mengevaluasi asuhan tindakan keperawatan, menggunakan komunikasi terapeutik dan hubungan interpersonal dalam pemberi pelayanan dan asuhan keperawatan, menciptakan dan mempertahankan lingkungan yang aman, membina hubungan interprofesional dalam pelayanan maupun asuhan keperawatan, menjalankan fungsi delegasi dan supervise baik dalam pelayanan maupun asuhan keperawatan (PPNI, 2013). Proses menjalankan tugas sebagai pemberi asuhan keperawatan, perawat berwenang untuk menegakkan diagnosis keperawatan (Pasal 30 UU No.38 tahun 2014). Kegiatan analisis data dalam perumusan diagnosa keperawatan merupakan kemampuan kognitif dalam pengembangan daya berfikir dan penalaran yang dipengaruhi oleh latar belakang ilmu dan pengetahuan yang dimiliki seorang perawat. Analisis data dalam perumusan diagnosa keperawatan dimulai dengan pengelompokan data yang diperoleh dari anamnesa, pengamatan dan pemeriksaan fisik lalu hasil yang didapat dibandingkan dengan standar (kondisi normal), sehingga dapat diketahui permasalahan kesehatan yang dialami pasien dan dapat dirumuskan masalah kesehatan. Saat melakukan analisis data untuk perumusan diagnosa keperawatan 
kemampuan seorang perawat sangat diperlukan untuk mengkaitkan data dan menghubungkan data tersebut dengan konsep teori, sehingga perawat mampu merumuskan diagnosa keperawatan dengan tepat (Dermawan, 2012). Diagnosa keperawatan adalah suatu kesimpulan yang dihasilkan dari analisa data (Carpenito, 2009). Diagnosa keperawatan adalah langkah kedua dari proses keperawatan yang menggambarkan penilaian klinis tentang respon individu, keluarga, kelompok maupun masyarakat terhadap permasalahan kesehatan baik aktual maupun potensial.

\section{Tujuan :}

Untuk mengetahui dan memahami Kompetensi perawat dalam memberikan asuhan keperawatan terutama dalam menentukan diagnose keperawatan.

\section{Metode :}

Metode yang digunakan dalam kajian ini adalah metode pengumpulan data dari beberapa artikel jurnal penelitian yang dipublikasi pada basis elektronik menggunakan metode tersearch dan analisis dari berbagai sumber seperti buku teks, referensi jurnal, dan e-book, dengan menggunakan Google Scholar,Portal Garuda dan Jurnal Keperawatan Indonesia. Yang berhubungan dengan kompetensi perawat dalam menentukan diagnosa keperawatan dalam asuhan keperawatan.

\section{Hasil :}

Asuhan keperawatan merupakan hal sangat penting bagi seorang perawat. Kemampuan pemberian pelayanan yang baik serta kemudian dapat secara efektif dapat mengkomunikasikan tentang perawatan pasien tergantung pada seberapa baik kualitas informasi yang diberikan serta dokumentasi yang disediakan untuk dimanfaatkan oleh semua profesional kesehatan dan antar bidang pelayanan kesehatan. ompetensi yang harus dimiliki perawat antara lain adalah : pengetahuan tentang aspek aspek penting dalam melakukan pengkajian, ketrampilan dalam melakukan diagnosa dan perencanaan keperawatan, dan sikap dalam melakukan tindakan keperawatan. 


\section{Pengkajian}

Proses keperawatan digunakan perawat sebagai kerangka berfikir untuk mengidentifikasi respon klien terhadap masalah kesehatan. Proses keperawatan menurut Nurahmah dan Manurung, S. (2011) mengatakan bahwa proses keperawatan terdiri dari 5 tahap : yaitu tahap pertama pengkajian keperawatan, tahap kedua identifikasi/analisis masalah (diagnosa 13 keperawatan), tahap ketiga perencanaan, tahap keempat implementasi dan tahap kelima evaluasi. Pengkajian adalah dasar utama dari proses keperawatan pengumpulan data yang akurat dan sistematis akan membantu penentuan status kesehatan dan pola pertahanan klien mengidentifikasi kekuatan dan kebutuhan klien, serta merumuskan diagnosis keperawatan.

\section{Diagnosa Keperawatan}

Setelah melakukan pengkajian langkah selanjutnya adalah penegakan diagnosa keperawatan berdasarkan data yang telah didapatkan. Diagnosa keperawatan adalah langkah kedua dari proses keperawatan, mengklarifikasi masalah kesehatan dalam ruang lingkup keperawatan. Proses diagnosa merupakan hasil dari analisis data dan identifikasi perawat dari respon klien terhadap masalah pelayanan kesehatan (Perry \& Potter, 2009). Diagnosis keperawatan adalah putusan klinis tentang respon klien, keluarga, atau komunitas terhadap masalah kesehatan yang aktual dan potensial atau proses kehidupan. Diagnosis keperawatan merupakan pernyataan yang menggambarkan respon aktual dan potensial klien terhadap masalah kesehatan yang boleh dan mampu ditangani oleh perawat (NANDA Internasional, 2007 dalam Perry \& Potter, 2009). Type diagnosis keperawatan ada 4, yaitu :

a) Diagnosa keperawatan aktual yang menggambarkan respon manusia terhadap kondisi kesehatan atau proses kehidupan yang terdapat dalam individu, keluarga/ komunitas. Diagnosa aktual menunjukkan bahwa data pemeriksaan yang ada sudah cukup untuk menegakkan diagnosis keperawatan. 
b) Diagnosis keperawatan resiko menggambarkan respon manusia terhadap kondisi kesehatan /proses kehidupan yang mungkin menyebabkan individu, keluarga atau komunitas menjadi rentan. Pengkajian utama untuk diagnosa resiko adalah data yang menunjang faktor resiko. Data tersebut termasuk faktor fisiologis, psikososial, keturunan, gaya hidup dan lingkungan yang meningkatkan kerentanan klien, atau kecendrungan berkembang kearah kondisi tersebut. Komponen diagnosis keperawatan resiko adalah masalah dan penyebab. Masalah yang bersifat resiko tinggi atau cendrung potensial adalah masalah yang mungkin timbuldan menjadi kesulitan dikemudian hariapabila tindakan pencegahan tidak dilaksanakan

c) Diagnosis keperawatan promosi keperawatan adalah penilaian klinis terhadap motivasi individu, keluarga, atau komunitas serta keinginan untuk meningkatkan kesejahteraan dan aktualisasi potensi kesehatan manusia sebagai ungkapan kesiapan untuk meningkatkan perilaku kesehatan tertentu, seperti nutrisi dan olah raga. Diagnosis promosi kesehatan dapat digunakan pada berbagai bidang kesehatan dan tidak membutuhkan tingkat kesejahteraan tertentu d. Diagnosis keperawatan sejahtera menggambarkan respon manusia terhadap tingkat kesejahteraan dalam individu, keluarga, atau komunitas yang memiliki kesiapan untuk peningkatan . Hal ini merupakan penilaian klinis tentang individu, keluarga, atau komunitas dalam transisi dari tingkat kesejahteraan tertentu ke tingkat kesejahteraan yang lebih tinggi. Diagnosa keperawatan adalah pernyataan yang jelas, singkat dan pasti tentang masalah klien serta penyebabnya yang dapat dipecahkan melalui tindakan keperawatan. 


\section{Pembahasanan :}

Didalam bidang kesehatan kompetensi umumnya menunjukkan profesionalitas dan pencapaian dalam standar yang ditentukan sebagai panduan untuk melakukan tindakan klinis, belajar, mengajar, dengan dasar standar yang berlaku dalam mencapai kinerja pelayanan kesehatan (Sarita 2009). Kompetensi perawat merupakan kemampuan perawat untuk melakukan tindakan keperawatan terintegrasi antara pengetahuan, keterampilan, sikap dan penilaian berdasarkan pendidikan dasar dan tujuan praktik keperawatan yang terukur sesuai dengan kinerja perawat. Dimana tujuannya adalah untuk tetap menjaga kualitas kesehatan dan keamanan pasien (Bartlett 2010). Penjabaran area kompetensi perawat indonesia Kerangka kerja kompetensi perawat dikelompokkan dalam ranah kompetensi menurut PPNI (2013) sebagai berikut:

a) Praktik professional, etis, legal dan peka budaya.

1. Bertanggung gugat terhadap praktik professional.

2. Melaksanakan praktik keperawatan dengan prinsip etis dan peka budaya.

3. Melaksanakan praktik secara legal.

b) Pemberi asuhan dan manajemen asuhan keperawatan. $\$

1. Menerapkan prinsip dasar dalam pemberian asuhan keperawatan dan pengelolaannya.

2. Melaksanakan upaya promosi kesehatan dalam pelayanan maupun asuhan keperawatan.

3. Melakukan pengkajian keperawatan.

4. Melakukan analisis data dan merumuskan diagnosa keperawatan.

5. Menyusun rencana keperawatan.

6. Melaksanakan tindakan keperawatan sesuai rencana.

7. Mengevaluasi asuhan tindakan keperawatan.

8. Menggunakan komunikasi terapeutik dan hubungan interpersonal dalam pemberi pelayanan dan asuhan keperawatan.

9. Menciptakan dan mempertahankan lingkungan yang aman. 
10. Membina hubungan interprofesional dalam pelayanan maupun asuhan keperawatan.

11. Menjalankan fungsi delegasi dan supervise baik dalam pelayanan maupun asuhan keperawatan

Dokumentasi asuhan keperawatan merupakan bagian dari proses asuhan keperawatan yang dilakukan secara sistematis dengan cara mencatat tahap-tahap proses perawatan yang diberikan kepada pasien. Dokumentasi asuhan keperawatan merupakan catatan penting yang dibuat oleh perawat baik dalam bentuk elektronik maupun manual berupa rangkaian kegiatan yang dikerjakan oleh perawat meliputi lima tahap yaitu:

1) pengkajian,

2) penentuan diagnosa keperawatan,

3) perencanaan tindakan keperawatan,

4) pelaksanaan/implementasi rencana keperawatan,

5) evaluasi keperawatan

Kriteria diagnosa keperawatan Kriteria antara lain sebagai berikut ( Nursalam, $2015)$ :

a) Status kesehatan dibandingkan dengan standar untuk menentukan kesenjangan.

b) Diagnosa keperawatan dihubungkan dengan penyebab kesenjangan dan pemenuhan kebutuhan pasien.

c) Diagnosa keperawatan dibuat sesuai dengan wewenang

d) Komponen diagnosa terdiri atas PE/PES

e) Pengkajian ulang dan revisi terhadap diagnosis berdasarkan data terbaru.

Perumusan diagnosa keperawatan dapat dilakukan dengan 2 cara, yakni:

1.Dengan rumus PESrumus $: \mathrm{DK}=\mathrm{P}+\mathrm{E}+\mathrm{SDK}=$ Diagnosa

Keperawatan $\mathrm{P}=$ Problem $/$ masalahE $=$ EtiologiS $=$ Symptom $($ gejala $)$

2. Rumus PErumus: $\mathrm{DK}=\mathrm{P}+\mathrm{E}$. 
Tujuan diagnosa keperawatan Tujuan diagnosa keperawatan untuk mengidentifikasi menurut Wahid \& Suprapto (2012) sebagai berikut:

a) Masalah dimana adanya respon klien terhadap status kesehatan atau penyakit.

b) Faktor yang menunjang atau menyebabkan suatu masalah.

c) Kemampuan klien untuk mencegah atau menyelesaikan masalah.

d) Mengkomunikasikan masalah klien pada tim kesehatan.

e) Mendemonstrasikan tanggung jawab dalam indentifikasi masalah klien.

f) Mengidentifikasi masalah utama untuk perkembangan intervensi keperawatan.

Komponen diagnosa keperawatan Komponen diagnosa keperawatan menurut Dermawan (2012) sebagai berikut:

A. Problem adalah gambaran keadaan pasien dimana tindakan keperawatan dapat diberikan. Masalah atau problem adalah kesenjangan atau penyimpangan dari keadaan normal yang seharusnya tidak terjadi. Tujuan : menjelaskan status kesehatan pasien secara jelas dan sesingkat mungkin. Diagnosis keperawatan disusun dengan menggunakan standart yang telah disepakati, supaya :

1) Perawat dapat berkomunikasi dengan istilah yang dimengerti secara umum.

2) Memfasilitasi dan mengakses diagnosa keperawatan.

3) Sebagai metode untuk mengidentifikasi perbedaan masalah keperawatan dengan masalah medis.

4) Meningkatkan kerjasama perawat dalam mendefinisikan diagnosis dari data pengkajian dan intervensi keperawatan.

B. Etiologi atau faktor penyebab adalah faktor klinik dan personal yang dapat merubah status kesehatan atau mempengaruhi perkembangan masalah. Merupakan pedoman untuk merumuskan intervensi. Unsur unsur dalam identifikasi etiologi meliputi unsur PSMM :

1. Patofisiologi penyakit : semua proses penyakit, akut atau kronis yang dapat menyebabkan atau mendukung masalah. 
2. Situasional : personal dan lingkungan (kurang pengetahuan, isolasi sosial).

3. Medikasi (berhubungan dengan program perawatan atau pengobatan) : keterbatasan institusi atau rumah sakit, sehingga tidak mampu memberikan perawatan.

4. Maturasional : adolensent (ketergantungan dalam kelompok), young adult (menikah, hamil, menjadi orang tua), dewasa (tekanan karier).

C. Sign and symptom Data subyektif dan obyektif yang ditemukan sebagai komponen pendukung terhadap diagnosa keperawatan. Sign and symptom (tanda dan gejala) adalah ciri, tanda atau gejala yang merupakan informasi yang diperlukan untuk merumuskan diagnosa keperawatan Komponen diagnosa keperawatan menurut PPNI (2010) terdiri dari masalah (P), etiologi atau penyebab (E) dan tanda atau gejala (S) atau terdiri dari masalah dengan penyebab (PE).

Langkah - langkah menentukan diagnosa keperawatan Langkah - langkah menentukan diagnosa keperawatan menurut Setiadi (2012) sebagai berikut:

a) Klasifikasi dan analisis data Klasifikasi atau memfokuskan data adalah mengelompokan data-data pasien atau keadaan tertentu dimana klien mengalami permasalahan kesehatan atau keperawatan berdasarkan kriteria permasalahannya. Analisis data adalah kemampuan mengkaitkan data dan menghubungkan data tersebut dengan konsep teori dan prinsip yang relevan untuk membuat kesimpulan dalam menentukan masalah kesehatan dan keperawatan pasien. Cara analisis data adalah:

1. Validasi data, meneliti kembali data yang terkumpul.

2. Mengelompokkan data berdasarkan kebutuhan biopsiko-sosial dan spiritual.

3. Membandingkan dengan standar.

4. Membuat kesimpulan tentang kesenjangan yang ditemukan. 
b) Interpretasi data

1. Menentukan kelebihan pasien. Jika pasien memenuhi standar kriteria kesehatan, perawat akan menyimpulkan bahwa pasien memiliki kelebihan dalam hal tertentu dan kelebihan ini dapat digunakan untuk membantu menyelesaikan permasalahan pasien.

2. Menentukan masalah pasien/ menyimpulkan Jika pasien tidak memenuhi standar kriteria kesehatan maka pasien tersebut mengalami keterbatasan dalam aspek kesehatannya dan memerlukan pertolongan.

3. Menentukan masalah pasien yang pernah dialami, tahap ini perawat menentukan masalah potensial pasien.

4. Penentuan keputusan.

a. Tidak ada masalah tetapi perlu peningkatan status dan fungsi (kesejahteraan) : tidak ada indikasi respon perawat, meningkatnya status kesehatan, adanya inisiatif promosi kesehatan.

b. Masalah kemungkinan. Pola mengumpulkan data untuk memastikan ada atau tidaknya masalah yang diduga.

c. Masalah aktual atau risiko. Pasien tidak mampu merawat karena pasien menolak masalah dan pengobatan.

d. Masalah kolaboratif. Konsultasikan dengan tenaga kesehatan profesional yang kompeten dan bekerja secara kolaboratif pada masalah tersebut.

c. Validasi data Pada tahap ini perawat memvalidasi data yang ada secara akurat yang dilakukan bersama pasien dan keluarga atau masyarakat. Validasi ini dilaksanakan dengan mengajukan pertanyaan yang reflekif kepada pasien atau keluarga tentang kejelasan interpretasi data.

d. Merumuskan diagnosa keperawatan Perumusan diagnosa keperawatan didasarkan pada identifikasi masalah dan kemungkinan penyebab. Selain itu perumusan diagnosa juga sesuai dengan kebutuhan pasien. 
Tipe diagnosa keperawatan sebagai berikut:

a. Diagnosa keperawatan aktual. Diagnosa keperawatan aktual adalah diagnosa menjelaskan masalah yang nyata terjadi saat ini. Pada diagnosa keperawatan aktual batasan karakteristiknya adalah tanda dan gejala yang bila terlihat dalam waktu yang sama mewakili diagnosa keperawatan. Batasan karakteristik dibedakan menjadi karakteristik mayor dan minor. Mayor setidaknya satu tanda harus ada untuk validasi diagnosa, minor mendukung bukti tetapi boleh tidak ada.

b. Diagnosa keperawatan risiko. Diagnosa keperawatan risiko adalah keputusan klinis yang divalidasi oleh faktor risiko. Tidak terdapat tanda dan gejala mayor.

c. Diagnosa keperawatan potensial. Diagnosa keperawatan potensial adalah diagnosa yang didasarkan atas kondisi sehat klien untuk mencapai tingkat kesehatan yang lebih tinggi.

d. Diagnosa keperawatan kemungkinan. Diagnosa keperawatan kemungkinan adalah pernyataan tentang masalah yang diduga akan terjadi, masih memerlukan data tambahan.

e. Diagnosa keperawatan sindroma Diagnosa keperawatan sindroma adalah sekelompok atau kumpulan dari beberapa diagnosa keperawatan yang terjadi secara bersamaan yang memiliki penyebab tunggal.

Manfaat dokumentasi asuhan keperawatan menurut beberapa aspek berikut :

1) Aspek hukum : Dokumentasi keperawatan yang dibuat merupakan aspek legal didepan hukum. Dokumentasi merupakan bukti catatan dari tindakan yang diberikan dan sebagai dasar untuk melindungi pasien, perawat dan institusi.

2) Kualitas pelayanan, komunikasi: Melalui audit keperawatan dokumentasi keperawatan dijadikan alat untuk mengukur dalam membandingkan antara tindakan yang diberikan dengan standar yang dijadikan rujukan. Dengan demikian dapat diketahui apakah dalam bekerja telah sesuai dengan standar yang ditetapkan. 
3) Keuangan: Dokumentasi yang baik dan teliti akan menjadi bukti bahwa tindakah telah dilakukan oleh perawat. Dan dengan dokumentasi ini maka besarnya jasa yang diberikan akan diberikan sesuai dengan aturan yang ditetapkan ditempat masing-masing.

4) Pendidikan: Dokumentasi keperawatan dapat dijadikan sebagai rujukan bagi siswa-siswa perawat.

5) Penelitian: Penelitian keperawatan dengan menggunkan data-data sekunder akan sangat bergantung dengan kualitas dari dokumentasi keperawatan yang dibuat. Kesalahan dalam membuat atau pengisian dokumentasi yang tidak lengkap akan membuat informasi tentang riwayat pasien menjadi kabur.

Berdasarkan kebutuhan manusia menurut Abraham Maslow yaitu dari kebutuhan dasar klien kepada kebutuhan yang lebih tinggi, dari kebutuhan fiologis sampai kebutuhan aktualisasi diri. Masalah klien sesuai dengan diagnosa yang ditegakkan maka yang menjadi prioritas utama adalah diagnosa yang mengancam jiwa, apabila tidak ditangani membahayakan klien yaitu masalah yang berhubungan dengan kebutuhan fisiologis seperti respirasi, sirkulasi, nutrisi, hidrasi, eliminasi, suhu, kesenangan fisik dan kebutuhan yang berpengaruh pada keselamatan dan keamanan misalnya ancaman lingkungan, dan rasa takut. Prioritas selanjutnya adalah diagnosa yang apabila tidak segera ditangani tidak membahayakan klien seperti masalah yang berpengaruh terhadap cinta dan rasa memiliki, masalah yang berpengaruh terhadap harga diri serta masalah yang berpengaruh kemampuan mencapai sasaran pribadi atau aktualisasi diri klien). Tindakan keperawatan disusun berdasarkan diagnosa keperawatan yang ditemukan pada klien. 


\section{Penutup:}

Unsur - unsur yang terdapat dalam diagnosa keperawatan yaitu pernyataan yang singkat, tegas, jelas (sitelas) tentang keadaan kesehatan pasien/klien. Pasien/klien meliputi individu, keluarga dan masyarakat baik yang sakit maupun yang sehat. masalah kesehatan yang dihadapi yaitu ketidaktahuan tentang bagaimana mengatasi kebutuhan hidupnya sehari-hariberhubungan dengan kesehatannya, ketidakmampuan pasien untuk mengatasi masalah kebutuhan hidupnya sehari berhubungan dengan kesehatannya, ketidakmampuan pasien atau klien memenuhi kebutuhan hidupnya sehari-hariberhubungan dengan kesehatan, berhubungan dengan masalah kesehatan yang dihadapimya, baik etiologi ataugejala yang dirasakan pasien. Pelayanan keperawatan merupakan bagian tidak terpisahkan dari pelayanan kesehatan yang berperan dalam mencapai derajat kesehatan yang optimal pada tatanan individu, keluarga dan masyarakat. Pelayanan keperawatan di rumah sakit sebagai ujung tombak yang mampu menjadi daya ungkit yang besar dalam upaya pembagunan kesehatan Profesionalisme perawat, khususnya pelayanan keperawatan di rumah sakit dimulai dari komitmen dan internalisasi perawat terhadap profesi keperawatan itu sendiri. Perawat dituntut memiliki kemampuan intelektual, teknikal, dan interpersonal serta bertanggung jawab terhadap tindakan yang dilakukan. Kompetensi perawat berhubungan erat dengan kemampuan dan motivasi kerja yang kuat dalam memberikan pelayanan. Kompetensi yang dimiliki perawat, tercermin pada pelaksanaan tugas keperawatan dalam pelayanan kepada pasien. 


\section{DAFTAR PUSTAKA}

Dinarti., Mulyanti, Y. (2017). Dokumen Keperawatan. Jakarta: Kementerian Kesehatan Republik Indonesia.

Dewi, I. P., Nurrohmah., Fadlurrahman, F. (2020). Analisis Pengetahuan Perawat Dalam Menentukan Diagnosis Asuhan Keperawatan Spriritual Islami di Rumah Sakit Syariah. Jurnal Ilmu Keperawatan Indonesia, 4(1), 73-78.

Hidayanti. (2014). Kerangka Konsep Sumber Teknis. Kemnkes Indonesia.

PPNI, T. P. S. D., 2017. Standar Diagnosis Keperawatan Indonesia Definisi dan Indikator Diagnostik Edisi 1. Dewan Pengurus Pusat PPNI ,. pp. 268.

PPNI., 2017. Standar diagnosa keperawatan indonesia. Dewan Pengurus Pusat. pp. 22.

Rinawati, P. (2018). Kompetensi Perawat Dalam Merumuskan Diagnosa Pada Pasien Ruang Rawat Inap RSUD Tugu Rejo Semarang. Skripsi FIK Universitas Muhammdiyah Semarang.

Rohmah, N., Walid, S. (2019). Proses Keperawatan Berbasis KKNI (Kerangka Kualifikasi Nasional Indonesia). Jakarta : AR-Ruzz Media.

Simamora, R. H., Bukit, E., Purba, J. M., \& Siahaan, J. (2017). Penguatan kinerja perawat dalam pemberian asuhan keperawatan melalui pelatihan ronde keperawatan di rumah sakit royal prima medan. Jurnal pengabdian kepada masyarakat, 23(2), 300-304.

Simamora, R. H. (2019). Socialization of Information Technology Utilization and Knowledge of Information System Effectiveness at Hospital Nurses in Medan, North Sumatra. Editorial Preface From the D esk of M anaging Editor..., 10(9).

Sumilat, N. P. (2017). Standart Pendokumentasian Asuhan Keperawatan Di BIUD RSUD Kota Baubau. Skripsi FKIP UIN Alauddin Makassar. 
Suryono., Nugroho, C. (2020). Kompetensi Perawat Mendokumentasikan Diagnosa Keperawatan Berdasarkan Standar Diagnosa Keperawatan Indonesia (SKDI). Jurnal Ilmu Kesehatan, 11(1),164-260.

Yanti, R. I., \& Warsito, B. E., 2013. Hubungan Karakteristik Perawat, Motivasi, Dan Supervisi Dengan Kualitas Dokumentasi Proses Asuhan Keperawatan. Jurnal Manajemen Keperawatan, 1(2),107-114.

Yusuf, A.H. (2018). Kompetensi \& Kewewenangan Perawat Dalam Menghadapi Masalah Legal Etik Praktik Keperawatan. Universitas Airlangga. 